\section{SYNTHESIS OF POLYFUNCTIONALLY SUBSTITUTED HETEROCYCLIC COMPOUNDS DERIVED FROM 5-CINNAMOYLAMINO-2-CYANOMETHYL-1,3,4- THIADIAZOLE}

MAHMOUD REFAEE MAHMOUD, MANAL MOHAMED EL-SHAHAWI*, FATMA SABER ABU EL-AZM, MOHAMED ABDEEN

Chemistry Department, Faculty of Science, Ain Shams University, 11566 Cairo, Egypt.

\title{
ABSTRACT
}

Cinnamoyl isothiocyanate $\mathbf{1}$ was reacted with 2-cyanoethanoic acid hydrazide $\mathbf{2}$ to afford 1-cyanoacetyl-4-substituted thiosemicarbazide 3 which on treatment with a mixture of glacial acetic acid and acetic anhydride gave the desired 5-cinnamoylamino-2-cyanomethyl-1,3,4-thiadiazole 4. Compound 4 was subjected to react with aromatic aldehydes, phenylisothiocyanate, carbon disulphide and arylidene malononitrile to give coumarin 5, thiazolidines 8,9 and 1,3,4-thiadiazolo[3,2-a]pyridine 13 derivatives. The structures of all synthesized compounds were ascertained by spectral and analytical data.

\section{INTRODUCTION}

Aroyl and acyl isothiocyanates are important reagents which can be transformed to variety of heterocyclic derivatives on reacting with polyfunctional molecules, either via addition followed by cyclization or via cycloaddition[1]. Treatment of aroyl and/or acyl isothiocyanates with acid hydrazids yields substituted thiosemicarbazides which undergo cyclization to different heterocyclic compounds depending on the reaction conditions. Under basic conditions, substituted thiosemicarbazides undergo cyclization to 1,2,4-triazole-3-thione derivatives[2-10]. On the other hand, under acidic conditions substituted thiosemicarbazides undergo dehydrative cyclization to 1,3,4-thiadiazole derivatives.[4,713].

The 1,3,4-thiadiazole moiety is one of those compounds at the apex of chemists attention owing to its biological and pharmaceutical importance. A literature survey shows that 1,3,4-thiadiazole derivatives exhibit antimicrobial [1418], anti-inflammatory $[18,19]$, antitumor [2023], antihyperlipidemic [24], anticonvulsant [25,26], antiviral [27], antioxidant [28], antifungal [29,30], antitubercular [31,32] and antide- pressant activities [33]. In addition, 1,3,4-thiadiazole have important technological uses as corrosion and oxidation inhibitors [34], metal complexation agents $[35,36]$ and in analytical fields [37]. In view of these fascinating and encouraging results and in continuation of our work on biologically active nitrogen and sulfur heterocycles [38-40], we have synthesized some 2,5-disubstituted 1,3,4-thiadiazoles by adopting a different methodology.

\section{RESULTS AND DISCUSSION}

In this investigation, the nucleophilic addition of 2-cyanoacetohydrazide 2 to cinnamoyl isothiocyanate $\mathbf{1}$ in refluxing dioxane afforded a mixture of two products which were easily separated by fractional crystallization. The soluble fraction in methanol was identified as 5-cinnamoylamino-2-cyanomethyl-1,3,4-thiadiazole $(63 \%) 4$ and the insoluble fraction recrystallized from dioxane and was identified as 4-cinnamoyl-1-(2-cyanoacetyl)thiosemicarbazide (17\%) 3. Compound 3 readily cyclized to the corresponding 1,3,4-thiadiazole derivative 4 using a mixture of acetic anhydride and glacial acetic acid (Scheme 1). 


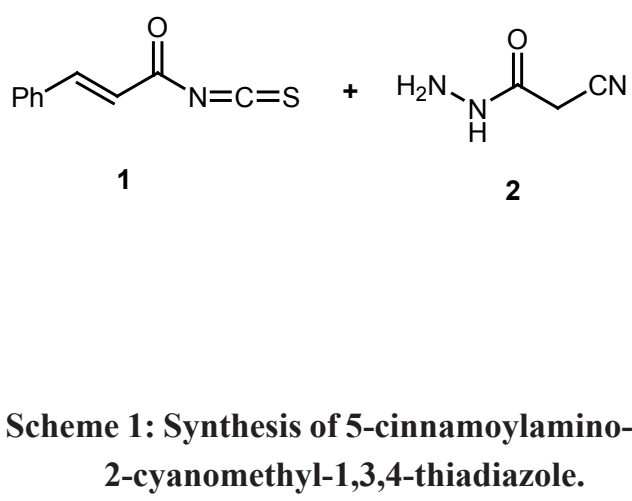

The structure of the acyclic product $\mathbf{3}$ was deduced from appropriate analytical and spectroscopic data. Thus, ${ }^{1} \mathrm{H}-\mathrm{NMR}$ spectrum (DMSO- $\mathrm{d}_{6}$ ) disclosed downfield three singlets each integrating for $1 \mathrm{H}(\mathrm{NH})$ at $\delta 12.5,11.7$ and 11.21 ppm, aromatic protons $(5 \mathrm{H})$ as a multiplet at $\delta$ 7.78-7.46 ppm together with two doublets each integrating for one hydrogen at $\delta 7.03$ and 6.98 ppm with coupling constant $\mathrm{J}=15$. Hz characteristic of trans olefinic protons. The cyanomethylene protons $(2 \mathrm{H})$ of the cyanoacetamide group appeared upfield at $\delta 3.86 \mathrm{ppm}$. Complete evidence for the acyclic structure $\mathbf{3}$ was forthcoming from the mass spectrum which showed the correct molecular ion peak at $\mathrm{m} / \mathrm{z}=288(74.2 \%)$. In addition, the base peak at $\mathrm{m} / \mathrm{z}=131$ attributable to the cinammoyl cation $\mathrm{PhCH}=\mathrm{CHCO}^{+}$is in harmony with the assigned structure 3. Cyclization of the thiosemicarbazide derivative 3 us-

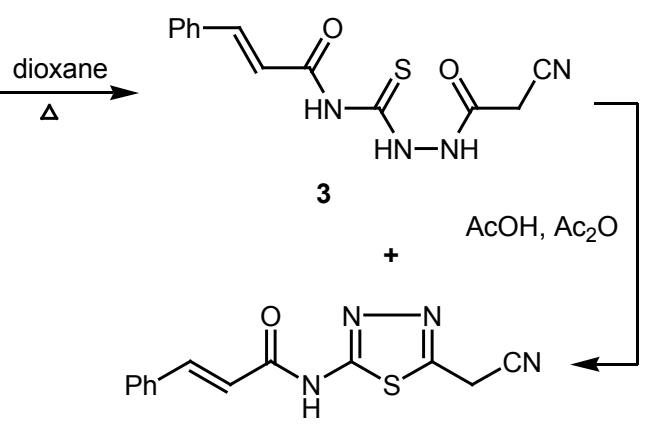

4

ing a mixture of glacial acetic acid and acetic anhydride afforded the 1,3,4-thiadiazole derivative 4 as the sole product (Scheme 1). The structure of compound 4 was deduced from its spectroscopic and analytical data.

The proclivity of compound 4 towards electrophilic reagents such as aromatic aldehydes, carbon disulfide, phenyl isothiocyanate and nucleophilic reagents such as hydrazine hydrate and hydrazides were investigated. Thus, the reaction of $\mathbf{4}$ with salicylaldehyde in refluxing dioxane in the presence of a catalytic amount of piperidine afforded the coumarin derivative 5. On the other hand, treatment of the acyclic product 3 with salicyaldehyde under the same conditions affords $\mathbf{6}$ which on treatment with a mixture of freshly distilled acetic anhydride and glacial acetic acid yielded coumarin derivative 5 (Scheme 2).

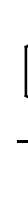

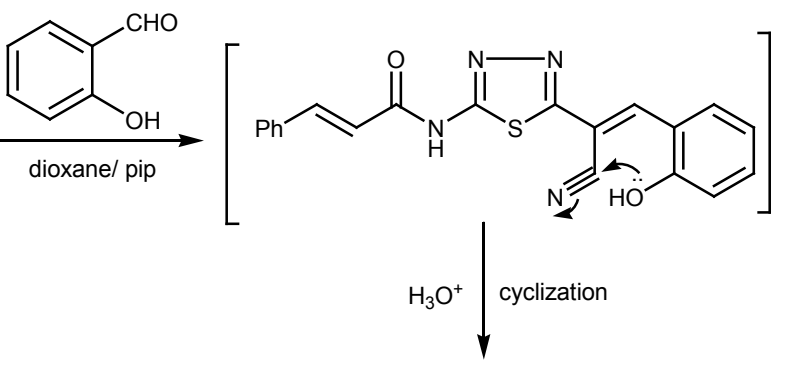<smiles>O=C(/C=C/c1ccccc1)Nc1nnc(-c2cc3ccccc3oc2=O)s1</smiles>

Scheme 2: Synthesis of 2-(2-Oxo2H-chromen-3-yl)-5- cinnamoylamino-1,3,4- thiadiazole<smiles>N#CCc1nnc(NC(=O)/C=C/c2ccccc2)s1</smiles>

4

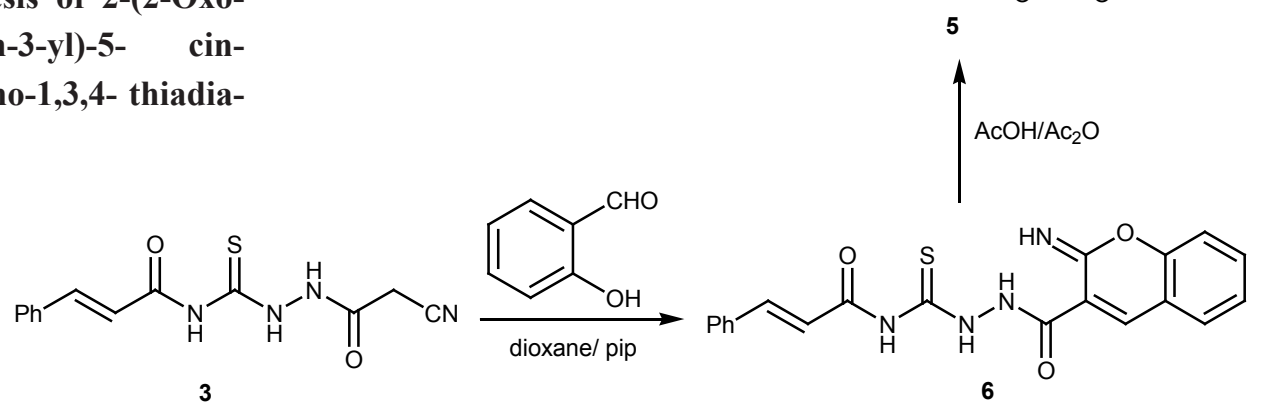

5 $\mathrm{AcOH} / \mathrm{Ac}_{2} \mathrm{O}$ 
The structure of coumarin derivative $\mathbf{5}$ was verified with microanalytical data and was confirmed by spectroscopic data. Therefore, the IR spectrum of 5 revealed the absence of a stretching band for the nitrile group and the presence of an oxo-coumarin band at $1712 \mathrm{~cm}^{-1}$. Moreover, the ${ }^{1} \mathrm{H}-\mathrm{NMR}$ spectrum of compound 5 displayed signals characteristic of the $\mathrm{NH}$ proton at $\delta 10.92 \mathrm{ppm}$ as a broad singlet that disappeared with $\mathrm{D}_{2} \mathrm{O}$, a singlet for the $\mathrm{C}_{4}-\mathrm{H}$ coumarin proton at $\delta 8.50 \mathrm{ppm}$, a multiplet for aromatic protons $(9 \mathrm{H})$ at $\delta 7.87-7.37 \mathrm{ppm}$ and two doublets for the trans-olefinic protons at $\delta 7.0$ and $6.90 \mathrm{ppm}$ which are in accord with the proposed structure 5. Furthermore, the highest recorded peak in the mass spectrum of 5 at $\mathrm{m} / \mathrm{z}=375(9.7 \%)$ repre- sents the molecular ion peak which upon loss of cinnamoyl radical yielded the base peak at $\mathrm{m} / \mathrm{z}=$ $245(100 \%)$.

On the other hand, treatment of 1,3,4-thiadiazole derivative 4 with 3,4-dimethoxybenzaldehyde in dioxane and in the presence of a catalytic amount of piperidine afforded the corresponding arylidene derivative 7 (Scheme 3). The structure of 7 was confirmed by the analytical and spectroscopic data. Thus, the IR spectrum of 7 showed one weak absorption band of $\mathrm{NH}$ at $3198 \mathrm{~cm}^{-1}$, $v_{\mathrm{C}=\mathrm{N}}$ (conjugated) at $2201 \mathrm{~cm}^{-1}$ and $v_{\mathrm{C}=0}$ at 1670 $\mathrm{cm}^{-1}$. The strong clue for the structure 7 was forthcoming from the study of its mass and ${ }^{1} \mathrm{H}$ NMR spectra which is compatible with the proposed structure.<smiles>COc1ccc(/C=C(\C#N)c2nnc(NC(=O)/C=C/c3ccc(C=O)cc3)s2)cc1/C=C/C(=O)Nc1nnc(C(C2=NC(=O)CS2)=C(c2ccc(OC)c(OC)c2)c2ccc(OC)c(OC)c2)s1</smiles>

Treatment of compound 4 with phenylisothiocyanate and elemental sulfur in presence of a catalytic amount of triethylamine in ethanol yielded the thiazole-2-thione derivative 9 (Scheme 4). The IR spectrum of compound 9 revealed the absence of the stretching band of the nitrile group and retained three weak bands of $\mathrm{NH}$ at $3453,3277,3142 \mathrm{~cm}^{-1}$ together with carbonyl stretching band at $1674 \mathrm{~cm}^{-1}$. Moreover, the ${ }^{1} \mathrm{H}-\mathrm{NMR}$ spectrum of compound 9 revealed signals characteristic for three types of protons which are consistent with the proposed structure 9. 


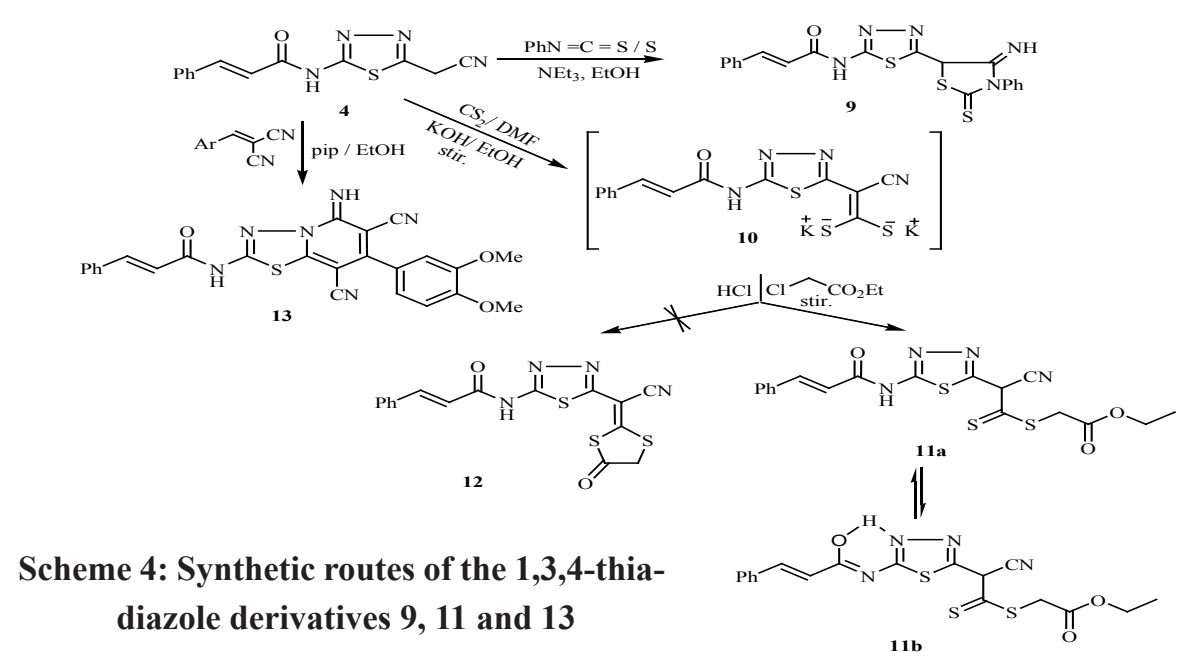

Stirring compound $\mathbf{4}$ with carbon disulphide in ethanolic potassium hydroxide $(10 \%)$ and dimethyl formamide for three hours yielded the dipotassium disulphide salt $\mathbf{1 0}$ which in situ added to ethyl chloroacetate followed by acidification with cold dilute hydrochloric acid gave the uncyclized product 11 (Scheme 4). No evidence was detected for the cyclized product 12 since the IR spectrum of the product obtained exhibited broad band at $3439 \mathrm{~cm}^{-1}$ (bonded $\mathrm{OH}, \mathrm{NH}$ ), $v_{\mathrm{C} \equiv \mathrm{N}}$ at $2202 \mathrm{~cm}^{-1}, v_{\mathrm{C}=\mathrm{O}}$ (ester) at $1727 \mathrm{~cm}^{-1}, v_{\mathrm{C}=\mathrm{O}}$ $\left(\alpha, \beta\right.$-unsaturated amide) at $1677 \mathrm{~cm}^{-1}$ and $v_{\mathrm{C}=\mathrm{N}}$ at $1624 \mathrm{~cm}^{-1}$.

Furthermore, when1,3,4-thiadiazole derivative 4 was subjected to react with 3,4-dimethoxy benzylidene malononitrile in refluxing ethanol in presence of a catalytic amount of piperidine, the 1,3,4-thiadiazolo[3,2-a]pyridine derivative 13 was obtained (Scheme 4). The structure 13 was substantiated from the microanalytical and spectroscopic data. Thus, the IR spectrum of $\mathbf{1 3}$ displayed $v_{\mathrm{NH}}$ at $3245(\mathrm{w})$ and $3224(\mathrm{w}), 3170$ $\mathrm{cm}^{-1}, v_{\mathrm{C}=\mathrm{N}}$ (conjugated) at $2216 \mathrm{~cm}^{-1}, v_{\mathrm{C}=\mathrm{O}}$ at $1687 \mathrm{~cm}^{-1}$ and $v_{\mathrm{C}=\mathrm{N}}$ at $1628 \mathrm{~cm}^{-1}$ which are agree well with the assigned structure. The ${ }^{1} \mathrm{H}-\mathrm{NMR}$ spectrum of $\mathbf{1 3}$ revealed the presence of a singlet downfield integrating for one proton $(\mathrm{NH})$ at $\delta$ 11.01 ppm which is exchangeable with $\mathrm{D}_{2} \mathrm{O}$, a broad singlet for $1 \mathrm{H}(=\mathrm{NH})$ at $8.18 \mathrm{ppm}$, a multiplet involved the aromatic and olefinic protons at $\delta 7.68-6.98 \mathrm{ppm}$ integrating for $10 \mathrm{H}$, and two singlets each integrating for $3 \mathrm{H}$ corresponding to the two methoxyl protons at $\delta 3.87$ and 3.84 $\mathrm{ppm}$. The formation of $\mathbf{1 3}$ could be formulated as depicted in Scheme $\mathbf{5}$.<smiles>N#CCc1nnc(NC(=O)/C=C/c2ccccc2)s1</smiles>

(4)

Scheme 5

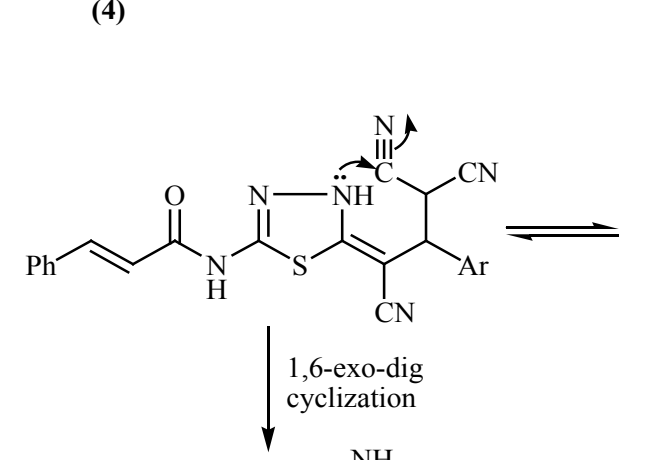<smiles>CC(C#N)C([Al])C(c1nnc(NC(=O)/C=C/c2ccccc2)s1)C(C)C#N</smiles><smiles>CC(C)c1ccccc1</smiles>

(13) 


\section{Experimental}

The melting points were measured on a Gallenkamp melting point apparatus. The FTIR spectra were recorded on a Pye Unicam SP-3300 spectrometer. ${ }^{1} \mathrm{H}-\mathrm{NMR}$ spectra were run on a Varian Mercury VX-300 NMR 300 MHz spectrometer. The mass spectra were recorded on Shimadzu GCMS-QP-1000EX mass spectrometers at 70e.V. Elemental analysis was performed by Vario EL-III elemental analysis.

\section{Synthesis of (3) and (4)}

Ammonium thiocyanate $(1 \mathrm{~g}, 0.01 \mathrm{~mol})$ was added to a solution of cinnamoyl chloride (1.66 $\mathrm{g}, 0.01 \mathrm{~mol})$ in dioxane $(10 \mathrm{ml})$ and then the reaction mixture was stirred for 10 minutes. The reaction mixture was filtrated off and the filtrate was added to a solution of cyanoacetohydrazide $(1 \mathrm{~g}, 0.01 \mathrm{~mol})$ in dioxane $(10 \mathrm{ml})$ and then the reaction mixture was heated under reflux for 15 minutes. The formed solid (two spots on TLC) was collected by filtration, dried, and fractionally crystallized from methanol to give 4 (63\%), while the residue was crystallized from dioxane to afford the 3 (17\%).

\section{4-Cinnamoyl-1-(2-cyanoacetyl)thiosemi- carbazide (3)}

white crystals, Yield: $17 \%$, mp: $235-236^{\circ} \mathrm{C}$; ${ }^{1} \mathrm{H}-\mathrm{NMR}\left(\mathrm{DMSO}_{6}\right) \delta(\mathrm{ppm}): 12.50(\mathrm{~s}, 1 \mathrm{H}$, $\mathrm{NH}$, exchangeable with $\left.\mathrm{D}_{2} \mathrm{O}\right), 11.71(\mathrm{~s}, 1 \mathrm{H}, \mathrm{NH}$, exchangeable with $\left.\mathrm{D}_{2} \mathrm{O}\right), 11.21(\mathrm{~s}, 1 \mathrm{H}, \mathrm{NH}$, exchangeable with $\left.\mathrm{D}_{2} \mathrm{O}\right), 7.78-7.46\left(\mathrm{~m}, 5 \mathrm{H}_{\text {arom. }}\right)$, $7.03(\mathrm{~d}, \mathrm{H}, \mathrm{PhCH}=, \mathrm{J}=15.4 \mathrm{~Hz}) 6.98(\mathrm{~d}, 1 \mathrm{H}$, $\mathrm{PhCH}=\mathrm{CH}, \mathrm{J}=15.4 \mathrm{~Hz}) 3.86\left(\mathrm{~s}, 2 \mathrm{H}, \underline{\mathrm{CH}}_{2} \mathrm{CN}\right)$; IR (KBr) v : 3297, $3221(\mathrm{NH}), 2267(\mathrm{CN}), 1680$, $1666(\mathrm{C}=\mathrm{O}) ; \mathrm{MS} \mathrm{m} / \mathrm{z}(\%): 288\left(\mathrm{M}^{+} ; 74\right), 270$ (21), 204 (24), 131 (100), 103 (90), 77 (89); Anal. Calcd. for $\mathrm{C}_{13} \mathrm{H}_{12} \mathrm{~N}_{4} \mathrm{O}_{2} \mathrm{~S}$ (288.315): C, 54.16; H, 4.19; N, 19.43; S, 11.12. Found: C, 54.10; H, 4.08; N, 19.39; S, 11.08 .

5-Cinnamoylamino-2-cyanomethyl-1,3,4thiadiazole (4)

white crystals, Yield: $63 \%$, mp: $218-220^{\circ} \mathrm{C}$; ${ }^{1} \mathrm{H}-\mathrm{NMR}\left(\mathrm{DMSO}-\mathrm{d}_{6}\right) \delta(\mathrm{ppm}): 11.72(\mathrm{~s}, 1 \mathrm{H}, \mathrm{NH}$, exchangeable with $\left.\mathrm{D}_{2} \mathrm{O}\right), 7.78-7.45\left(\mathrm{~m}, 5 \mathrm{H}_{\text {arom }}\right)$, $7.03(\mathrm{~d}, 1 \mathrm{H}, \mathrm{PhCH}=, \mathrm{J}=15.7 \mathrm{~Hz}), 6.98(\mathrm{~d}, 1 \mathrm{H}$, $\mathrm{PhCH}=\mathrm{CH}, \mathrm{J}=15.7 \mathrm{~Hz}), 3.86\left(\mathrm{~s}, 2 \mathrm{H}, \underline{\mathrm{CH}}_{2} \mathrm{CN}\right)$; IR (KBr) v: $3158(\mathrm{NH}), 2252(\mathrm{CN}), 1691(\mathrm{C}=\mathrm{O})$,
$1634(\mathrm{C}=\mathrm{N}) ; \mathrm{MS} \mathrm{m} / \mathrm{z}(\%): 270\left(\mathrm{M}^{+} ; 21\right), 202$ (20), 131 (6), 76 (46), 69 (100). Anal. Calcd. for $\mathrm{C}_{13} \mathrm{H}_{10} \mathrm{~N}_{4} \mathrm{OS}$ (270.302): C, 57.77; $\mathrm{H}, 3.73$; N, 20.73; S, 11.86. Found: C, 57.80; H, 3.70; N, $20.68 ; \mathrm{S}, 11.80$.

\section{Cyclization of (3)}

Thiosemicarbazide derivative $3(1 \mathrm{~g})$, freshly distilled acetic anhydride $(10 \mathrm{ml})$ and glacial acetic acid $(10 \mathrm{ml})$ was heated under reflux for $2 \mathrm{hrs}$. The reaction mixture was concentrated and then poured into ice/cold water. The yielded solid was separated by filtration, washed with water, dried, and recrystallized from methanol to give 4 (identity M.P., mixed M.P., IR and TLC comparison).

2-(2-Oxo-2H-chromen-3-yl)-5- cinnamoylamino-1,3,4-thiadiazole (5).

A mixture of thiadiazole 4 (2.7 g, 0.01 mol), salicylaldehyde $(1.23 \mathrm{ml}, 0.01 \mathrm{~mol})$ and piperidine $(0.5 \mathrm{ml})$ in dioxane $(20 \mathrm{ml})$ was refluxed for $2 \mathrm{hrs}$. The reaction mixture was concentrated and then poured into ice/cold water and acidified with concentrated hydrochloric acid. The yielded solid was separated by filtration, washed with water, dried, and recrystallized from ethanol/ dioxane mixture (7:3) to give 5 as yellow crystals, Yield: 51\%, mp: 228$230^{\circ} \mathrm{C}$; ${ }^{1} \mathrm{H}-\mathrm{NMR}$ (DMSO-d $\left.{ }_{6}\right) \delta$ (ppm): 10.92 (s, $1 \mathrm{H}, \mathrm{NH}$, exchangeable with $\left.\mathrm{D}_{2} \mathrm{O}\right), 8.50(\mathrm{~s}, 1 \mathrm{H}$, $\mathrm{C}_{4}-\mathrm{H}$ coumarin), 7.87-7.37 ( $\left.\mathrm{m}, 9 \mathrm{H}_{\text {arom }}\right), 6.92(\mathrm{~d}$, $1 \mathrm{H}, \mathrm{PhCH}=, \mathrm{J}=15.4 \mathrm{~Hz}), 6.54(\mathrm{~d}, 1 \mathrm{H}, \mathrm{PhCH}=\mathrm{CH}$, $\mathrm{J}=15.4 \mathrm{~Hz})$. IR (KBr) v: $3190(\mathrm{NH}), 1712,1689$ $(\mathrm{C}=\mathrm{O}), 1636(\mathrm{C}=\mathrm{N}) ; \mathrm{MS} \mathrm{m} / \mathrm{z}(\%): 375\left(\mathrm{M}^{+} ; 10\right)$, 245 (100), 172 (79), 146 (71), 131 (90), 103 (98), 77 (78). Anal. Calcd. for $\mathrm{C}_{20} \mathrm{H}_{13} \mathrm{~N}_{3} \mathrm{O}_{3} \mathrm{~S}$ (375.392): C, 63.99; H, 3.49; N, 11.19; S, 8.54. Found: C, 63.92; H, 3.52; N, 11.10; S, 8.58.

4-Cinnamoyl-1-(2-imino-2H-chromene3-carbonyl)thiosemicarbazide (6).

To a solution of compound 3 ( $2.88 \mathrm{~g}, 0.01$ $\mathrm{mol})$ in dioxane $(20 \mathrm{ml})$, salicylaldehyde $(1.23$ $\mathrm{ml}, 0.01 \mathrm{~mol})$ was added with piperidine $(0.2$ $\mathrm{ml}$ ), and then the reaction mixture was refluxed for $3 \mathrm{hrs}$. After evaporation of excess solvent and acidification with dilute cold hydrochloric acid the solid separated was collected by filtration, washed with water, dried, and then recrystal- 
lized from dioxane to give $\mathbf{6}$, yellowish- white crystals, Yield: $43 \%$, mp: $208-210^{\circ} \mathrm{C}$; IR $(\mathrm{KBr})$ v: 3254, $3158(\mathrm{NH}), 1691(\mathrm{C}=\mathrm{O}), 1634(\mathrm{C}=\mathrm{N})$; MS m/z (\%): $392\left(\mathrm{M}^{+} ; 14\right), 245$ (79), 206 (40), 173 (41), 146 (92), 131 (100), 103 (89), 77 (99). Anal. Calcd. for $\mathrm{C}_{20} \mathrm{H}_{16} \mathrm{~N}_{4} \mathrm{O}_{3} \mathrm{~S}$ (392.419): C, 61.22; H, 4.11; N, 14.28; S, 8.17. Found: 61.18; $\mathrm{H}, 4.17 ; \mathrm{N}, 14.32 ; \mathrm{S}, 8.10$.

\section{Cyclization of (6)}

Thiosemicarbazide derivative $6(1 \mathrm{~g})$, acetic anhydride $(10 \mathrm{ml})$ and glacial acetic acid $(10 \mathrm{ml})$ was heated under reflux for $2 \mathrm{hrs}$. The reaction mixture was concentrated and then poured into ice/cold water. The yielded solid was collected by filtration, washed with water, dried, and recrystallized from dioxane to give 5 (identity M.p., mixed M.p., IR and TLC comparison).

2-[1-Cyano-2-(3,4-dimethoxyphenyl)vinyl]5- cinnamoylamino-1,3,4-thiadiazole (7).

A mixture of thiadiazole $4(2.7 \mathrm{~g}, 0.01 \mathrm{~mol})$, 3,4-dimethoxybenzaldehyde (1.66 g, $0.01 \mathrm{~mol})$ and piperidine $(0.5 \mathrm{ml})$ in ethanol $(20 \mathrm{ml})$ was refluxed for $1 \mathrm{hr}$. The produced solid on hot was separated by filtration, dried, and recrystallized from dioxane to give 7 as yellow crystals, Yield: 48\%, mp:160-162 ${ }^{\circ} \mathrm{C} ;{ }^{1} \mathrm{H}-\mathrm{NMR}$ (DMSO-d ${ }_{6}$ ) $\delta$ (ppm): $11.68(\mathrm{~s}, 1 \mathrm{H}, \mathrm{NH}$, exchangeable with $\left.\mathrm{D}_{2} \mathrm{O}\right), 8.20(\mathrm{~s}, 1 \mathrm{H}, \underline{\mathrm{CH}}=), 7.78-7.73\left(\mathrm{~m}, 3 \mathrm{H}_{\text {arom. }}\right)$, 7.71-7.47 $\left(\mathrm{m}, 5 \mathrm{H}_{\text {arom }}\right), 7.20(\mathrm{~d}, 1 \mathrm{H}, \mathrm{PhCH}=, \mathrm{J}=$ $15.2 \mathrm{~Hz}), 7.04(\mathrm{~d}, 1 \mathrm{H}, \mathrm{PhCH}=\mathrm{CH}, \mathrm{J}=15.2 \mathrm{~Hz})$, $3.88\left(\mathrm{~s}, 3 \mathrm{H}, \mathrm{OCH}_{3}\right), 3.83\left(\mathrm{~s}, 3 \mathrm{H}, \mathrm{OCH}_{3}\right)$; IR $(\mathrm{KBr})$ v: $3189(\mathrm{NH}), 2201(\mathrm{C} \equiv \mathrm{N}), 1670(\mathrm{C}=\mathrm{O}), 1618$ $(\mathrm{C}=\mathrm{N}) ; \mathrm{MS} \mathrm{m} / \mathrm{z}(\%): 418\left(\mathrm{M}^{+} ; 23.9\right), 288(23)$, 151 (54), 131 (100), 103 (99), 77 (55). Anal. Calcd. for $\mathrm{C}_{22} \mathrm{H}_{18} \mathrm{~N}_{4} \mathrm{O}_{3} \mathrm{~S}$ (418.455): C, 63.15; $\mathrm{H}$, 4.33; N, 13.39; S,7.66. Found: C, 63.20; H, 4.29; N, 13.35; S, 7.70.

2-[2-(3,4-Dimethoxyphenyl)-1-(4-oxo-4,5dihydrothiazol-2-yl)vinyl]- 5- cinnamoyl- amino-1,3,4-thiadiazole (8).

A mixture of arylidene derivative $7(2.1 \mathrm{~g}$, $0.005 \mathrm{~mol})$ and mercaptoacetic acid $(0.46 \mathrm{~g}$, $0.005 \mathrm{~mol})$ and in pyridine $(15 \mathrm{ml})$ was heated under reflux for $7 \mathrm{hrs}$. The reaction mixture was concentrated and then poured into ice/cold water and acidified with concentrated hydrochloric acid. The yielded solid was separated by filtra- tion, washed with water, dried, and recrystallized from methanol to give $\mathbf{8}$, pale yellow crystals, Yield: $47 \%$, mp: $270-272^{\circ} \mathrm{C}$; IR (KBr) v: $3196(\mathrm{NH}), 1695(\mathrm{C}=\mathrm{O}), 1630(\mathrm{C}=\mathrm{N}) ; \mathrm{MS} \mathrm{m} / \mathrm{z}$ (\%): $492\left(\mathrm{M}^{++} ; 1\right), 459$ (2), 287 (11), 260 (11), 216 (21), 151 (100), 131 (64), 103 (36), 77 (55). Anal. Calcd. for $\mathrm{C}_{24} \mathrm{H}_{20} \mathrm{~N}_{4} \mathrm{O}_{4} \mathrm{~S}_{2}$ (492.556): C, 58.52; H, 4.09; N, 11.37; S,13.02. Found: C, 58.48; H, 3.99; N, 11.42; S, 13.08 .

2-(4-Imino-3-phenyl-2-thioxothiazolidin5-yl)-5-cinnamoylamino-1,3,4-thiadiazole (9).

A mixture of arylidene derivative 7 (2.1 g, $0.005 \mathrm{~mol})$, phenylisothiocyanate $(0.65 \mathrm{ml}$, $0.005 \mathrm{~mol})$, elemental sulfur $(0.16 \mathrm{~g}, 0.005 \mathrm{~mol})$ and triethylamine $(0.5 \mathrm{ml})$ in ethanol $(20 \mathrm{ml})$ was heated under reflux for $4 \mathrm{hrs}$. The produced solid after cooling was separated by filtration, dried, and recrystallized from dioxane to give 9 as yellow crystals, Yield: $47 \%$, mp: $270-272^{\circ} \mathrm{C} ;{ }^{1} \mathrm{H}-$ NMR $\left(\right.$ DMSO-d $\left._{6}\right) \delta(\mathrm{ppm}): 11.28(\mathrm{~s}, 1 \mathrm{H},=\mathrm{NH}$, exchangeable with $\left.\mathrm{D}_{2} \mathrm{O}\right), 10.36(\mathrm{~s}, 1 \mathrm{H}, \mathrm{NH}$, exchangeable with $\left.\mathrm{D}_{2} \mathrm{O}\right), 7.44-7.35\left(\mathrm{~m}, 12 \mathrm{H}, 10 \mathrm{H}_{\mathrm{a}}\right.$ rom $+2 \mathrm{H}$ olefinic protons), $4.92\left(\mathrm{~s}, 1 \mathrm{H}, \mathrm{C}_{5}-\mathrm{H}\right.$ of thiazole ring); IR (KBr) v: 3453, 3277, $3142(\mathrm{NH})$, $1674(\mathrm{C}=\mathrm{O}), 1280(\mathrm{C}=\mathrm{S}) ; \mathrm{MS} \mathrm{m} / \mathrm{z}(\%): 437$ $\left(\mathrm{M}^{+}\right.$; 9), 307 (10), 208 (70), 131 (91), 103 (92), 77 (90). Anal. Calcd. for $\mathrm{C}_{20} \mathrm{H}_{15} \mathrm{~N}_{5} \mathrm{OS}_{3}$ (437.552): C, 54.90; H, 3.45; N, 16.00; S,21.99. Found: C, $54.95 ; \mathrm{H}, 3.40 ; \mathrm{N}, 16.05 ; \mathrm{S}, 21.92$.

2-[Ethyl 2-(2-cyanoethanethioylthio) acetate]-5-cinnamoylamino-1,3,4-thiadiazole (11).

The thiadiazole 4 ( $2.7 \mathrm{~g}, 0.01 \mathrm{~mol})$ was added to a cold suspension of finally deviated potassium hydroxide $(0.56 \mathrm{~g}, 0.01 \mathrm{~mol})$ in dry dimethyl formamide $(20 \mathrm{ml})$ and then the reaction mixture was stirred for 15 minutes. Carbon disulphide $(0.76 \mathrm{ml}, 0.01 \mathrm{~mol})$ was added drop wise and the reaction mixture was allowed to stand for 3 hrs. The reaction mixture was cooled to $0^{\circ} \mathrm{C}$ and stirred with ethyl chloroacetate $(1.23 \mathrm{ml}, 0.01$ $\mathrm{mol})$ at room temperature for $3 \mathrm{hrs}$ and then allow to stand overnight. The reaction mixture was poured into ice/cold water and acidified with concentrated hydrochloric acid. The obtained solid was separated by filtration, washed with water, dried, and recrystallized from methanol to give $\mathbf{1 1}$ as pal yellow crystals, Yield: $75 \%$, 
mp: $180-182^{\circ} \mathrm{C} ;{ }^{1} \mathrm{H}-\mathrm{NMR}$ (DMSO-d $\left.{ }_{6}\right) \delta$ (ppm): $10.28\left(\mathrm{~s}, 1 \mathrm{H}, \mathrm{NH}\right.$, exchangeable with $\left.\mathrm{D}_{2} \mathrm{O}\right)$, 7.64-7.48 (m,5H $\left.\mathrm{H}_{\text {arom }}\right), 7.06(\mathrm{~d}, 1 \mathrm{H}, \mathrm{PhCH}=, \mathrm{J}=$ $15.4 \mathrm{~Hz}), 6.96(\mathrm{~d}, 1 \mathrm{H}, \mathrm{PhCH}=\mathrm{CH}, \mathrm{J}=15.4 \mathrm{~Hz}$ ), 4.23 (s, 1H, $\underline{\mathrm{CHCN}}$ ), 4.207 (q, 2H, $\underline{\mathrm{CH}}_{2} \mathrm{CH}_{3}, \mathrm{~J}=$ $7.2 \mathrm{~Hz}), 4.21\left(\mathrm{~s}, 2 \mathrm{H}, \mathrm{S} \mathrm{CH}_{2} \mathrm{CO}\right), 1.22(\mathrm{t}, 3 \mathrm{H}$, $\left.\mathrm{CH}_{2} \underline{\mathrm{CH}}_{3}, \mathrm{~J}=7.2 \mathrm{~Hz}\right)$; IR $(\mathrm{KBr})$ v: $3439(\mathrm{NH})$, $2202(\overline{\mathrm{C}} \equiv \mathrm{N}), 1727,1677(\mathrm{C}=\mathrm{O}), 1624(\mathrm{C}=\mathrm{N})$; MS m/z (\%): $432\left(\mathrm{M}^{+}, 11\right), 386$ (11), 358 (2), 267 (4), 229 (6), 131 (17), 103 (8), 77 (11). Anal. Calcd. for $\mathrm{C}_{18} \mathrm{H}_{16} \mathrm{~N}_{4} \mathrm{O}_{3} \mathrm{~S}_{3}$ (432.528): C, 49.98; $\mathrm{H}$, 3.72; N, 12.95; S, 22.24. Found: 49.92; H, 3.68; N, 13.05; S, 22.30.

2- Cinnamoylamino -6,8-dicyano-7-(3,4dimethoxyphenyl) - 5 -imino- $5 \mathrm{H}-1,3,4$ thiadiazolo[3,2-a]pyridine (13).

A mixture of thiadiazole $4(2.7 \mathrm{~g}, 0.01 \mathrm{~mol})$, 3,4-dimethoxybenzylidene malononitrile (2.2 $\mathrm{g}, 0.01 \mathrm{~mol})$ and piperidine $(0.5 \mathrm{ml})$ in ethanol $(20 \mathrm{ml})$ was refluxed for $6 \mathrm{hrs}$. The solid formed after concentration was separated by filtration, dried, and recrystallized from dioxane to give $\mathbf{1 3}$ as light brown crystals, Yield:48\%, mp: $270-272^{\circ} \mathrm{C} ;{ }^{1} \mathrm{H}-\mathrm{NMR}\left(\mathrm{DMSO}-\mathrm{d}_{6}\right) \delta(\mathrm{ppm})$ : 11.01 (s, 1H, NH, exchangeable with $\left.\mathrm{D}_{2} \mathrm{O}\right), 8.18$ $\left(\mathrm{s}, 1 \mathrm{H},=\mathrm{NH}\right.$, exchangeable with $\left.\mathrm{D}_{2} \mathrm{O}\right)$, 7.68$6.98\left(\mathrm{~m}, 10 \mathrm{H}, 8 \mathrm{H}_{\text {arom }} .+2 \mathrm{H}\right.$ olefinic proton $), 3.87$ $\left(\mathrm{s}, 3 \mathrm{H}, \mathrm{OCH}_{3}\right), 3.84\left(\mathrm{~s}, 3 \mathrm{H}, \mathrm{OCH}_{3}\right)$; IR $(\mathrm{KBr})$ v: 3245, 3224, $3170(\mathrm{NH}), 2216(\mathrm{C} \equiv \mathrm{N}), 1687$ $(\mathrm{C}=\mathrm{O}), 1628(\mathrm{C}=\mathrm{N})$; $\mathrm{MS} \mathrm{m} / \mathrm{z}(\%)$ : $456\left(\mathrm{M}^{+}{ }^{+} \mathrm{CN}\right.$; 28), 441 (98), 417 (50), 247 (20), 131 (100), 103 (89), 77 (54). Anal. Calcd. for $\mathrm{C}_{25} \mathrm{H}_{18} \mathrm{~N}_{6} \mathrm{O}_{3} \mathrm{~S}$ (482.500): C, 62.23; H, 3.73; N, 17.42; S,6.65. Found: $62.23 ; \mathrm{H}, 3.46 ; \mathrm{N}, 17.46 ; \mathrm{S}, 6.70$.

\section{REFERENCES}

[1] Elmoghayar, M. R.H.; Abdalla, S.O.; Nasr, M.Y. A. J. Heterocyclic Chem. 198, 21, 781-784 and references 1-4 therein.

[2] Zi-Yi, Z.; Li-min, C.; Xiao-Ming, F.; Fu-Li, Z. Youji Нuaxue 1989, 9, 150.

[3] Sharba, A. H. K.; Al-Bayati R.H.; Aouad M.; Rezki N. Molecules. 2005, 10, 1161-1168.

[4] Kucukguzel G.S.; Kucukguzel I.; Tatar E.; Rollas S.; Sxahin F.; Gulluce M.; Clercq E. D; Kabasakal L. Eur. J. Med. Chem. 2007, 42(7), 893-901.

[5] Bayrak, H.; Demirbas, A.; Demirbas, N.; Karaoglu, S. A. Eur. J. Med. Chem. 2010, 45(11), 4726-4732.

[6] Moallem, S. A., Hadizadeh, F.; Abadi, F. A.; Shahraki,
M.; Shamsara, J. Iran J. Basic Med. Sci. 2012, 15(4), 945-950.

[7] Dabholkar, V.V.; Gavande, R. P. Acta Poloniae Pharmaceutica-Drug Research. 2012, 69(2), 247-252.

[8] El-Mariah, F.; Hosny, M.; Deeb, A. Phosphorus, Sulfur, Silicon. 2006,181(4), 809-818.

[9] Salgın-Goksen, U.; Gokhan-Kelekci, N.; Goktas, O.; Koysal, Y.; Kilic, E.; Isik, S.; Aktay, G.; Ozalp, M. Bioorg. Med. Chem. 2007, 15(7), 5738-5751.

[10] Taha, M. A. M.; El-Badry, S. M. Phosphorus, Sulfur, Silicon 2007, 182(5), 1011-1021.

[11] Thaker, K. M.; Joshi, H. S. Indian J. Chem. 2005 , 44B, 410-412.

[12] Guzeldemirci, N.U.; Kucukbasmaci, O. Eur. J. Med. Chem. 2010, 45(1), 63-68.

[13] Abd alla, M. S. M.; Hegab, M. I.; Taleb, N. A. A.; Hasabelnaby, S. M.; Goudah, A. Eur. J. Med. Chem. 2010, 45(4),1267-1267.

[14] Barbuceanu, S. F.; Saramet, G.; Almajan, G. L.; Barbuceanu, C. D. F.; Bancescu, G. Eur J Med Chem. 2012, 49, 417-423.

[15] Tanveer, A.; Arvind, K.; Nupur, J.; Deepika, S. International Research Journal of Pharmacy. 2012, 3(3), 70-82.

[16] Nitin, D.; Gopkumar, P.; Sujit, P. Research and Reviews: Journal of Chemistry. 2014, 3(2), 50-53.

[17] Kerura, S.; Alagawadi, K.; Zhu, H.; Manvi, F. Eur J Med Chem. 2012, 3(3), 293-297.

[18] Kadi, A. A.; Al-Abdullah, E. S.; Shehata, I. A.; Habib, E. A.; Ibrahim, T. M.; El-Emam, A. A. Eur J Med Chem. 2010, 45, 5006-5011.

[19] Verma, A. K.; Martin, A. Int J of Pharm Arch. 2014, 3(9), $1-5$.

[20] Kumar, S.; Hegde, M.; Gopalakrishnan, V.; Renuka, V. K.; Ramareddy, S. A.; De Clercq E.; Schols, D.; Narasimhamurthy, A. K. G.; Raghavan, S. C.; Karki, S. S. Eur J Med Chem. 2014, 84, 687-697.

[21] Gireesh, T. M.; Kamble, R. R.; Taj, T; Kattimani, P. P.; Meti, G. Y. Med Chem Res. 2013, 22(9), 4367-4375.

[22] Kumar, D.; Vaddula, R.; Chang, K.; Shah, K. Bioorg. Med. Chem. Lett. 2011, 21, 2320-2323.

[23] Xu, F.; Jia, Y.; Wen, Q.; Wang, X.; Zhang, L.; Zhang, Y.; Yang, K.; Xu, W. Eur J Med Chem. 2013, 64, 377388.

[24] Patel, H. M.; Noolvi, M. N.; Goyal, A.; Thippeswamy, B. S. Eur J Med Chem. 2013, 65, 119-133.

[25] Karakus, S.; Kocyigit-Kaymakcioglu, B.; Toklu, H. Z.; Ariciogiu, F.; Rollas, S. Archiv der Pharmazi. 2009, 342(1), 47.

[26] Rahman, A.; Shakya, A.K.; Wahab, S.; Ansari, N. H. Bulgarian Chem Commun. 2014, 46(4), 750-756. 
Mahmoud Refaee Mahmoud, et al.

[27] Chen, Z.; Xu, W.; Liu, K.; Yang, S.; Fan, H.; Bhadury, P. S.; Hu, D.; Zhang, Y. Molecules. 2010, 15, 9046-9056.

[28] Soni, B. K.; Singh, T.; Bhalgat, C. M.; Kamlesh, B.; Kumar, S. M.; Pavani, M. International Journal of Research in Pharmaceutical and Biomedical Sciences. 2011, 2(4), 1590-1592.

[29] Matysiak, J.; Malinski, Z. Russ J Bioorg Chem. 2007, 33, 594-601.

[30] Zhang, L.; Yang, M.; Sun, Z.; Tan, C.; Weng, J.; Wu, H.; Liu, X. Letters in Drug Design \& Discovery 2014, 11()), 1107-1111.

[31] Karigar, A. A.; Himaja, M.; Male, S. V.; Prathap, K. J.; Sikarwar, M. S. Int Res J Pharm 2011, 2(1), 153-158.

[32] Alegaon, S. G.; Alagawadi, K. R.; Sonkusare, P. V.; Chaudhary, S. M.; Dadwe, D. H.; Shah, A. S. Bioorg Med Chem Lett. 2012, 22(5), 1917-1921.
[33] Cleici, F.; Pocar, D.; Guido, M.; Loch, A.; Perlini, V.; Brufani, M. J. Med. Chem. 2001, 44(6), 931-936.

[34] Gao, Y.; Zhang, Z.; Xue, Q. Mat. Res. Bull. 1999, 34(12-13),1867-1874.

[35] Frański, R. J. Mass. Spectrom. 2004, 39(6), 705.

[36] Bentiss, F.; Lebrini, M.; Lagrenée, M. J. Heterocyclic Chem. 2004, 41, 419.

[37] Ahmed, M.; Jahan, J.; Banco, S. A. J. anal. Sci. 2002, $18,805-810$.

[38] Mahmoud, M. R.; El-Ziaty, A. K.; Abu El-Azm, F. S. M.; Ismail, M. F.; Shiba, S. A. J Chem Res. 2013, 37(2), 80-85.

[39] Mahmoud, M. R.; Shiba, S.; El-Ziaty, A. K.; Abu ElAzm, F. S. M.; Ismail, M. F. Synth. Commun. 2014, 44,1094-1102.

[40] Mahmoud, M. R.; Abu El-Azm, F. S. M.; Ali, A. T.; Ali, Y. M. Synth. Commun. 2015, 45, 982-992. 